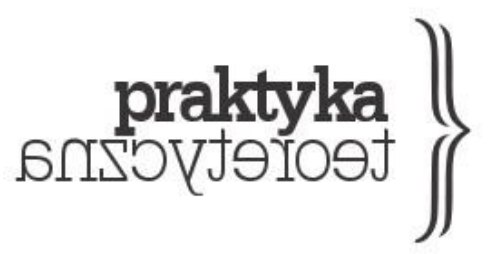

\title{
RELIGIA, FEMINIZM I IMPERIUM: \\ NOWE AMBASADORKI ISLAMOFOBII
}

\author{
SABA MAHMOOD \\ PRZEEOŻYŁa: JOANNA BEDNAREK \\ PRZEKŁad PRZERZAła: MONIKA BOBAKO
}

\begin{abstract}
Abstrakt: Tekst omawia zjawisko uwikłania niektórych nurtów współczesnego feminizmu w odtwarzanie dyskursu islamofobicznego. Autorka prezentuje postaci takie jak Azar Nafisi, Irshad Manji czy Ayaan Hirsi Ali - publicystki i działaczki przedstawiające skrajnie negatywny obraz islamu jako religii ze swojej istoty nakłaniajaccej do przemocy i uciskającej kobiety. Taka wizja islamu jest bliska ideologii konserwatywnej i świetnie wpisuje się w zachodnie projekty imperialistyczne, takie jak wojna $z$ terroryzmem czy interwencje na Bliskim Wschodzie dokonywane pod pretekstem „wprowadzania demokracji”. Jak pokazuje autorka, część zachodnich feministek, np. Margaret Atwood czy Susan Sontag, nie dostrzega tego faktu i bezkrytycznie przyjmuje dyskurs wspomnianych krytyczek islamu. Postaci te odgrywaja więc rolę „ambasadorek islamofobii”, legitymizując swoje stanowisko jako „feministyczne” i ,postępowe”.
\end{abstract}

Słowa kluczowe: feminizm, islamofobia, imperializm, wojna z terroryzmem 
Teza o skomplikowanej roli, jaka zachodni feminizm odegrał w sankcjonowaniu i ekspansji rządów kolonialnych na rozległych obszarach Azji, Afryki i Środkowego Wschodu, została dobrze udokumentowana i uargumentowana ${ }^{1}$. Dla wielu $z$ nas, wychowanych w tej tradycji krytycznej, zaskakujące jest zatem powtórne pojawienie się w nowych gatunkach literatury feministycznej tego starego, kolonialnego dyskursu na temat kobiet; jego jawnym celem jest przy tym usprawiedliwienie amerykańskiej „wojny z terroryzmem” toczonej na terenie świata muzułmańskiego. Obnażanie po raz kolejny pokrętnej logiki, za pomocą której zachodnia potęga imperialna próbuje uzasadnić swoja geopolityczną dominację, udając „wyzwoliciela” tubylczych kobiet spod władzy rdzennej patriarchalnej kultury, wydaje się nieraz niewdzięcznym zadaniem. Można sądzić, że ta pod względem ideologicznym niezbędna, ale nużąca dla intelektu praca wymaga niewiele inwencji i polega tylko na powtórzeniu ustaleń wcześniejszych prac naukowych na temat Algierii, Egiptu, Indonezji oraz Indii, szczegółowo i wnikliwie rekonstruujących splot historii feminizmu i imperium.

Ważne jest jednak to, by feministki przyjrzały się związkowi współczesnego dyskursu feministycznego i euroamerykańskiej imperialnej dominacji na Bliskim Wschodzie. Choć zwyczajni Amerykanie i Europejczycy utracili, jak się wydaje, entuzjazm dla promowanej przez Busha i Blaira strategii jednostronnego militaryzmu (tak w Iraku, jak i w Afganistanie czy Iranie), to nadal jednak wierza oni politykom i medialnym ekspertom twierdzącym, że społeczeństwa muzułmańskie zostały opanowane przez fundamentalistyczną ideologię, której głównymi ofiarami są należące do tych społeczeństw kobiety. Twierdzenie to zakłada również normatywną wizję, zgodnie z którą rozwiązanie polega na promowaniu w świecie islamu „demokracji” oraz zachodnich „wolności i swobód” za pomocą reform religijnych i kulturalnych, tak by skłonić muzułmanów do zwalczenia ich fundamentalistycznych skłonności i przyjęcia bardziej oświeconej wersji islamu. W niniejszym tekście interesuje mnie głównie rola, jaką w historii tej odgrywaja wolność, demokracja i równość płci, oraz łatwość, z jaką złe traktowanie kobiet w islamie wykorzystywane jest jako diagnoza, a zarazem punkt strategiczny umożliwiający interwencję i przekształcenie licznych kręgów społeczeństwa muzułmańskiego, jeśli nie samej religii. W jaki sposób idee wolności, demokracji i równości płci - konstytutywne dla wielu tradycji składających się na myśl feministyczna - umożliwiają rozwój obecnego euroamerykańskiego dążenia do stworzenia muzułmanów i islamu na nowo? Co owe idee zacieraja i jakie formy przemocy tolerują? Aby uniknąć nieporozumień, chciałabym wyjaśnić, co rozumiem przez „liberalny feminizm”: używam tego terminu na określenie nurtów w obrębie feminizmu, w ramach których powiązania między określonymi analizami nierówności płci i polityką imperialną są najgęstsze i najtrwalsze. Zdaję sobie sprawę

\footnotetext{
${ }^{1}$ Rozległa literatura na ten temat obejmuje między innymi: Ahmed 1992; Alloula 1986; Lazreg 1994 i Spivak 1988.
} 
z tego, że istnieją również takie tradycje myśli feministycznej, które są krytyczne wobec tych uwikłań2.

\section{Rdzenne świadectwa}

Empiryczny obszar pozwalający mi na przemyślenie tych zagadnień wyznacza szereg wydanych niedawno, należących do literatury faktu bestsellerów napisanych przez muzułmańskie kobiety i dotyczących cierpień, jakich kobiety te doświadczyły z racji jakoby nieporównywalnie mizoginicznych praktyk islamu. Po wydarzeniach z 11 września ów niezwykle popularny podgatunek autobiograficzny odegrał kluczową rolę w umocnieniu przekonania, że złe traktowanie kobiet w islamie jest symptomem jego głębszych patologii - przede wszystkim skłonności [muzułmanów] do przemocy. Wezwania do reformy islamu, formułowane na równi przez podmioty postępowe, liberalne i konserwatywne, zawsze wiążą się z poruszaniem kwestii ucisku kobiet. Argument jest prosty: kobiety stanowią najbardziej nieszczęśliwe ofiary ideologii islamskiego fundamentalizmu. Rozwiązaniem byłoby wprowadzenie do świata muzułmańskiego „demokracji”, na czym kobiety nie tylko by skorzystały, ale także stałyby się protagonistkami tej zmiany. W czasach imperialnej pewności siebie wydaje się, że los muzułmańskich kobiet i los demokracji są ze sobą trwale związane.

Wiele autorek owych świadectw zostało sowicie wynagrodzonych przez konserwatywne partie polityczne i think tanki z różnych krajów, a niektóre z nich zostały wyniesione na stanowiska polityczne mimo niewielkich kwalifikacji innych niż zdolność prowadzenia agresywnej polemiki z islamem. Ze względu na swoje publiczne znaczenie autorki tworzące w tym gatunku odgrywają dziś quasi-oficjalną rolę w polityce amerykańskiej i europejskiej: legitymizuja, a nieraz i przewodzą zderzeniu cywilizacji „Zachodu i islamu”.

Jak jednak zobaczymy, autorki te sa popularne nie tylko w konserwatywnych, ale także w liberalnych i postępowych kręgach, które przymykają oko na typowe dla owego gatunku kiepski styl i przesadę, uznając je za nieistotne w obliczu jego rzeczywistej zalety: ujawniania prawdy o muzułmańskiej mizoginii. Ideologiczna siła tych książek polega w dużej mierze na zajmowaniu przez ich autorki podwójnej pozycji: wtajemniczonej informatorki i zarazem ofiary, podmiotu kluczowego dla orientalistycznego ujęcia sytuacji kobiet w społeczeństwach muzułmańskich. Te autobiograficzne prace różnią się jednak od wcześniejszych kolonialnych świadectw, w których to Europejczycy musieli ujawniać cierpienia miejscowych kobiet.

Fakt, że ten rodzaj autobiografii muzułmańskich kobiet przemawia także do licznych feministek, z których wiele przeciwstawia się imperialistycznej polityce prowadzonej wobec

\footnotetext{
2 Obszerniejsza krytyka stosunku liberalnego feminizmu do islamu znajduje się w mojej pracy Politics of Piety (2005), zwł. w rozdziale pierwszym.
} 
islamu, jest szczególnie niepokojący. Kilka znanych krytyczek feministycznych poleca te książki, niektóre spośród owych bestsellerów znajdują sie w programach studiów kobiecych, a przynajmniej sa powszechnie znane przez ich uczestniczki³. Choć za ich popularność odpowiada po części fakt, że są one traktowane jako autentyczne „głosy muzułmanek”, to źródłem wzruszenia i zachwytu, jakie wywołują one u feministycznej publiczności, jest model emancypacyjnej polityki, na którym się one opieraja. To właśnie owemu modelowi emancypacyjnemu oraz towarzyszącym mu topografiom świeckiej polityki i pragnienia liberalnych swobód chciałabym się przyjrzeć w niniejszym tekście.

Poniżej postawię trzy powiązane ze soba, ale odrębne tezy. Pierwsza część tekstu dotyczyć będzie symbiotycznego związku łączącego autorki wspomnianej muzułmańskiej literatury kobiecej i konserwatywne partie oraz think tanki z USA i Europy - związku, który powinien osłabić nieco entuzjastyczny odbiór owych książek w kręgach feministycznych. Druga część tekstu poświęcona będzie analizie typowych dla tych autobiograficznych relacji pominięć i nieścisłości, które umożliwiły skonstruowanie opozycji między zachodnią cywilizacją i muzułmańskim barbarzyństwem (czy też fundamentalizmem). Na koniec zaś, w trzeciej części, przeanalizuję popularne argumenty na rzecz wprowadzenia demokracji w świecie islamu oraz rolę, jaką pełni w nich figura uciskanej muzułmańskiej kobiety. Zwracam uwagę na szczególną, redukcyjną koncepcję religijności, która obecna jest w aktualnych wezwaniach do demokratyzowania świata muzułmańskiego i która cieszy się poparciem wielu feministek (Pollitt 2002). Koncepcja ta wymaga krytyki z powodu zawartej w niej przemocy i ograniczonej wizji emancypacji, jaka proponuje. W części tej pokażę też, w jaki sposób liberalny dyskurs dotyczący wolności, odtwarzany przez wiele nurtów myśli feministycznej, czyni nas ślepymi na rolę, jaką nieliberalna forma religijności odgrywa w życiu wielu kobiet. Jeśli feministki rzeczywiście chca zaznaczyć swój dystans wobec imperialnej polityki naszych czasów, ważne jest to, by zrozumiały, poznały i uszanowały te formy religijności, zamiast nimi gardzić i odrzucać je jako wyraz fałszywej świadomości.

Jednym z najsłynniejszych przykładów owej muzułmańskiej literatury kobiecej jest Cayytajac Lolitę w Teheranie Azar Nafisi. Od momentu publikacji w 2003 roku książka ta znajdowała się na liście bestsellerów New York Timesa przez 117 tygodni, została przetłumaczona na ponad 32 języki i zdobyła kilka prestiżowych nagród literackich. Choć tekst Nafisi wyróżnia się walorami estetycznymi i literackimi, co czyni go wyjątkowym wśród omawianych tu prac, łączy go z nimi konsekwentne pomijanie faktów, które mogłyby skomplikować opowieść o ucisku kobiet w społeczeństwach muzułmańskich.

Druga książka, która odniosła ogromny sukces - choć w odróżnieniu od poprzedniej nie pretenduje do miana literatury pięknej - to Kłopot z islamem kanadyjskiej dziennikarki Irshad

\footnotetext{
${ }^{3} \mathrm{Na}$ temat Azar Nafisi zob. np. Atwood 2003; na temat Carmen bin Laden zob. Ehrenreich 2004.
} 
Manji. Przetłumaczono ją na ponad 20 języków, w 23 krajach miała powtórne wydania, a w Kanadzie znajdowała się na liście bestsellerów przez 20 tygodni podczas pierwszego roku po publikacji. Agresywne diatryby Manji przeciwko islamowi pomogły jej zdobyć znacząca pozycję: regularnie pojawia się ona w programach wielu stacji telewizyjnych (w tym BBC, CNN i Fox News); komentarze jej autorstwa ukazują się w prestiżowych dziennikach (takich jak New York Times, Times of London, International Herald Tribune czy Sydney Morning Herald); jest też zapraszana do wygłaszania wykładów na elitarnych uniwersytetach, mimo że jej teksty i wystąpienia pełne są błędów historycznych i zamierzonych nieścisłości dotyczących islamu.

Trzeci przykład tego typu publikacji, Rozdarty czarczaf. Moje sycie w Arabii Saudyjskiej Carmen bin Laden, to opowieść o małżeństwie autorki z jednym z 25 braci Osamy bin Ladena i spędzonych w Arabii Saudyjskiej latach duszącej (choć luksusowej) nudy. Książka ta została przełożona na 16 języków; prawa do przekładu sprzedano do ponad 27 krajów; znajdowała się na liście bestsellerów we Francji przez kilka miesięcy od chwili jej publikacji, a także na liście bestsellerów New York Timesa podczas pierwszego roku po publikacji.

We Francji kilka tego typu książek zdobyło dużą popularność w czasie, gdy przyjmowana była kontrowersyjna ustawa zabraniająca noszenia chust (oraz innych „,widocznych” symboli religijnych). Najsłynniejsza z nich to Ni putes, ni soumises [„Ani dziwki, ani uległe"] Fadeli Amary; książka ta zdobyła dwie prestiżowe nagrody literackie (Le Prix du livre politique i Le Prix des députés w 2004 roku), sprzedała się w ponad 50000 egzemplarzy i została przełożona na wiele języków. Nakład jej drugiej części, Ni putes, ni soumises, le combat continue [„Ani dziwki, ani uległe: walka trwa”, został w całości wyprzedany już przed publikacją. Równie popularnym pierwszoosobowym świadectwem poświadczającym barbarzyńskość obyczajów islamu jest Bas les voiles! [„Precz z chustami!’] irańskiej dysydentki Chahdortt Djavann z 2003 roku; cytat umieszczony na obwolucie książki dobrze oddaje pozycję, z której pisane są teksty należące do tego gatunku: „Nosiłam chustę przez dziesięć lat. Miałam wybór między chustą a śmiercią. Wiem, o czym mówię".

Zarówno Amara, jak i Djavann przedstawiły przed Komisją Stasiego (wyznaczonym przez rząd organem dochodzeniowym zalecającym wprowadzenie zakazu) osobiste świadectwa-protesty przeciwko noszeniu chust, które ponoć doprowadziły członków Komisji do łez. Udramatyzowane wypowiedzi tych kobiet, potraktowane w raporcie Komisji Stasiego jako „dowody” opresyjnego charakteru chusty, odegrały kluczową rolę w nastawieniu francuskiej opinii publicznej przeciwko chustom i stworzeniu klimatu powszechnej awersji do islamskich symboli religijnych oraz do mizoginii, którą miały one wyrażać.

Inne kraje europejskie, w tym Holandia, Hiszpania, Szwecja i Niemcy, również roszczą sobie prawo do posiadania własnych ambasadorek ofiar patriarchalnego ucisku islamu. Autorki te uwierzytelniaja i legitymizuja falę islamofobii przetaczająca się obecnie przez Europę, uzasadniając najgorsze uprzedzenia i stereotypy, jakie kontynent ten widział od czasu ekspansji 
antysemityzmu w latach trzydziestych. Owe autentyczne głosy muzułmanek odegrały ważna rolę w budowaniu poparcia dla wielu ustaw antyimigracyjnych, które uderzają w najbiedniejsze i najsłabsze grupy społeczne. Rola, którą pełnia „krytyczki islamu”, nie jest błaha, dlatego też ich wkład w sprawę spotyka się z uznaniem sił konserwatywnych współczesnej Europy i USA, które oferuja tej grupie zaszczyty i korzyści.

\section{Neokonserwatyzm i cierpienia kobiet}

Przyjrzyjmy się osobliwej karierze, jaką zrobiła w holenderskiej polityce Ayaan Hirsi Ali. Ta pochodząca z Somalii polityczka nie miała żadnych osiagnięć publicznych, dopóki nie zdecydowała się wykorzystać nastrojów antymuzułmańskich, które upowszechniły się w Europie po wydarzeniach z 11 września. Wyrzucając muzułmanom ich nieporównywalne z niczym barbarzyństwo i mizoginię, zyskała aprobatę prawicy po tym, jak zaatakowała prowadzoną przez holenderski rząd politykę socjalną i politykę wielokulturowości za propagowanie i wspieranie w jej ramach kultury przemocy domowej, rzekomo nieodłącznej od islamu i muzułmanów. W efektownych wystapieniach publicznych Hirsi Ali opisywała proroka Mahometa jako zboczeńca i despotę, twierdząc, że muzułmanom brak „oświeconej myśli, tolerancji i znajomości innych kultur” oraz że w ich dziejach nie sposób znaleźć ani jednej osoby, która „dokonałaby odkrycia naukowego lub technologicznego czy zmieniła świat dzięki osiagnięciom artystycznym" (Hirsi Ali 2006, 152-153; Kuper 2004). Niedługo potem Partia Ludowa na rzecz Wolności i Demokracji zaoferowała jej miejsce na liście kandydatów do parlamentu; w powszechnym głosowaniu w styczniu 2003 roku zdobyła mandat mimo skromnych kwalifikacji do zajmowania takiego stanowiska.

Holenderskie służby imigracyjne odkryły, że Hirsi Ali skłamała, by zyskać prawo wstępu do Holandii: jej historia o ucieczce przed wymuszonym małżeństwem i żądną zemsty rodziną okazała się zmyślona. W obliczu groźby pozbawienia jej holenderskiego obywatelstwa Hirsi Ali zrezygnowała ze stanowiska w parlamencie, ale zaraz potem otrzymała posadę w American Enterprise Institute, prestiżowym prawicowym think tanku w Waszyngtonie. Jak można się było spodziewać, opublikowała ona również pamiętniki zatytułowane The Caged Virgin: An Emancipation Proclamation for Women and Islam [,„Uwięziona dziewica: deklaracja emancypacji dla kobiet i islamu’]. Tytuł ten bardzo przypomina dziewiętnastowieczne przykłady literatury poświęconej orientalistycznym fantazjom na temat haremów (por. Alam 2006). Pomimo faktu, że osobista historia cierpień Hirsi Ali spowodowanych przez islamskie zwyczaje została zdyskredytowana, a jej książka jest pełna absurdalnych tez (na przykład: „,[muzułmańskie] dzieci uczą się od swoich matek, że kłamstwo się opłaca. Nieufność jest czymś powszechnym, a kłamstwa dominuja"; 2007, 25-26), publikacja ta spotkała się z całkiem dobrym przyjęciem. Prawa do przekładu zakupiło 15 krajów, a autorkę uznaje się za ważną osobistość w polu 
„konserwatywnej krytyki lewicowej”. Nadmiar i przesada nieźle się sprzedają: lewicowi krytycy tacy jak Christopher Hitchens (2007) chwala publikacje Hirsi Ali, otrzymała ona też w lutym 2008 roku Nagrodę na rzecz Wolności im. Simone de Beauvoir.

Argumenty wspomnianych autorek sprawiają wrażenie gotowych wzorów dla neokonserwatywnego planu zmiany ustroju na Bliskim Wschodzie. Szczególnie dobrze unaocznia to przykład Irshad Manji. W jej książce Kłopot z islamem (2005) zdumiewające jest wyolbrzymienie, jakiemu ulegaja neokonserwatywne strategie i argumenty - formułowane zawsze z pozycji rzekomo samokrytycznej, reformistycznie nastawionej muzułmanki, która chce sprowadzić swoich zagubionych braci na właściwą drogę. Choć prowokacyjna przesada jest dla tego gatunku typowa, Manji używa dodatkowo języka, który ma ranić i obrażać uczucia muzułmanów. Jej książka naszpikowana jest zdaniami opisującymi ich jako „cierpiących na Martwicę Mózgu”, „ograniczonych”, „niezdolnych do myślenia”, „obłudnych”, „żałośnie plemiennych” i „pławiących się w żalu nad sobą” (2005, 32, 40, 41, 230). Prezentuje ona islam jako bardziej literalistyczny, sztywny, nietolerancyjny, totalitarny, antysemicki i wrogi wobec kobiet oraz homoseksualistów niż jakakolwiek inna religia, a także opisuje jego rytuały jako bardziej skłaniające do „bezmyślnego posłuszeństwa [...] i uległości” wobec władzy. Potępieniu islamu i muzułmanów przez Manji towarzyszy bezgraniczny entuzjazm zarezerwowany dla „Zachodu”, „chrześcijaństwa”, ,judaizmu” i „Izraela”. Historia Zachodu nie ma dla niej sobie równych, jeśli chodzi o tolerancję, „pragnienie odkrywania”, „otwartość na nowe idee" i tak dalej (2005, 27, 30, 221-233).

Podobnie jak Hirsi Ali, Manji opowiedziała się za amerykańską inwazją na Afganistan i Irak, a później za dokonanym przez Izrael zniszczeniem Libanu latem 2006 roku - wszystko to w imię oczyszczenia świata muzułmańskiego z , islamskich fanatyków i terrorystów” (2006a). W swojej książce przedstawia Izraelczyków, w iście manichejskim stylu, jako wzory cnoty, zdolne do samokrytyki i tolerancji, podczas gdy Palestyńczyków potępia za tworzenie kultury oskarżeń i wiktymizacji. Posuwa się wręcz do tego, by określić dyskryminację arabskich obywateli przez Izrael jako formę „działań afirmatywnych” (2005, 125). Manji jest promowana przez proizraelską organizację lobbystyczną Middle East Media Research Institute (MEMRI) i niesławnego Daniela Pipesa, który napisał pochwalną recenzję jej książki i w towarzystwie którego pojawiała się ona na izraelskich imprezach mających na celu zbiórkę pieniędzy.

Pomimo świetnych stosunków, jakie Manji utrzymuje z neokonserwatywnymi luminarzami, nie należy lekceważyć ogólnej rozpoznawalności, jaką udało jej się zdobyć. Jej polemiki ukazują się w znaczących międzynarodowych dziennikach; jest także regularnie zapraszana do wygłaszania wykładów przez kolegia i uniwersytety oraz proszona o komentowanie wydarzeń politycznych o międzynarodowym znaczeniu w najważniejszych programach telewizyjnych i radiowych. Recenzenci jej książek często życzliwie przechodzą do porządku dziennego nad błędami merytorycznymi i polemicznymi uproszczeniami 
charakterystycznymi dla jej prac. W jednej z wczesnych recenzji, opublikowanej przez New York Times, Andrew Sullivan (2004) pisze na przykład:

Klopot z islamem to praca godna zapamiętania. Nie jest to szczególnie erudycyjny czy naukowy traktat na temat historii czy teologii islamu; obecne w niej wycieczki na teren geopolityki są chaotyczne i nieco naiwne; retoryczna przesada może nieraz sprawiać wrażenie sensacjonalizmu [...]. Przenikający tę książkę duch jest jednak wyraźny i stanowi coś, co już dawno powinno było się pojawić. Jej lektura jest jak objawienie. Manji, kanadyjska dziennikarka i osobowość telewizyjna, robi to, na co czekało wielu z nas: pociaga do odpowiedzialności fundamentalistyczny islam za tolerowanie w sobie takiego zła. I czyni to od wewnątrz (10, podkr. - SM).

Ostatnie zastrzeżenie jest wymowne: muzułmańska tożsamość Manji nadaje szczególną moc jej orientalistycznym i rasistowskim poglądom, pozwalając jej dotrzeć do odbiorców, do których nie mogliby dotrzeć ideolodzy w rodzaju Bernarda Lewisa czy Daniela Pipesa. Tym, co (poza jadowitymi atakami na islam) czyni ją tak cenną dla kogoś pokroju Sullivana, jest „szczególny liberalny ton” - przy czym liberalizm ten, jak pisze Sullivan, „nie dąży do zlikwidowania wiary, ale do ustanowienia z nią nowego związku. Jeśli uda nam się przetrwać obecną wojnę bez poniesienia niewyobrażalnych ofiar, stanie się to dzięki takiemu właśnie liberalizmowi, który nie stracił swojego wyczucia. Manji jest zakończeniem nerwowym Zachodu - obnażonym, sprawiającym ból, ale na szczęście nadal żywym”. Zwróćmy uwagę na opatrznościową rolę, jaką wyobrażenia te mają odegrać w świecie muzułmańskim. Są one nie tylko zwiastunem radości i miłosierdzia dla Irakijczyków, których kraj został zniszczony przez okupujące go amerykańskie wojsko, ale i obietnica całkowitego przeorganizowania relacji każdego muzułmanina i muzułmanki z jego czy jej wiara.

\section{Wybiórcze pominięcia}

W poniższej części artykułu skupię się na sposobie, w jaki pominięcia i nieścisłości obecne w omawianych publikacjach przyczyniły się do utrwalenia jednowymiarowego obrazu islamu. Wykorzystując w tym celu cieszącą się ogromnym uznaniem książkę Azar Nafisi, Cåytajac Lolitę w Teheranie (2005), pokażę, że przywołanie kilku faktów dotyczących niedawnych zmian w irańskiej polityce może skomplikować dokonany przez autorkę opis życia kobiet w porewolucyjnym Iranie i tym samym stworzyć jego zupełnie inny jego obraz ${ }^{4}$. Zamiast proponowanej przez Nafisi uproszczonej wizji „płciowego apartheidu” otrzymamy bardziej

\footnotetext{
${ }^{4}$ Najbardziej wyczerpująca interpretacja tekstu Nafisi jako przykładu rozwijającej się dynamicznie „,nowej literatury orientalistycznej" to: Keshavarz 2007.
} 
zniuansowane ujęcie porewolucyjnej polityki w Iranie, które może skłonić świeckie feministki do zrewidowania wielu ich założeń na temat islamu, nierówności płci i emancypacji politycznej.

Książka Nafisi Caytają Lolitę w Teheranie bardzo różni się od książek Manji i Hirsi Ali $z$ racji swoich pretensji literackich i obecnych w niej odwołań do wielkich „zachodnich klasyków”. W gruncie rzeczy znaczna część popularności tej narracji bierze się z faktu, że dzięki grze prowadzonej z subtelnym arcydziełem Nabokova staje się ona strawna dla odbiorców, którzy pozostają krytyczni wobec oczywistego oportunizmu dwóch pozostałych publikacji. Jest to prowadzona w pierwszej osobie opowieść irańskiej profesorki literatury anglojęzycznej (samej Nafisi), która po rezygnacji z pracy na uniwersytecie z powodu frustracji wywołanej kontrola duchownych nad programem nauczania, gromadzi grupę swoich studentek, by we własnym domu prowadzić z nimi zajęcia poświęcone klasycznej literaturze zachodniej. Nafisi wykorzystuje te spotkania nie tylko do potępienia klerykalnych rządów, ale i do tego, aby dać wyraz swojej głębokiej odrazie do irańskiego życia kulturalnego - zarówno współczesnego, jak i historycznego. Maluje przygnębiający obraz życia w porewolucyjnym Iranie - życia pozbawionego piękna, barw, inspiracji, poezji, dyskusji i sporów publicznych. W tym dusznym otoczeniu tylko zachodni kanon literacki daje jakąkolwiek nadzieję na wybawienie, dzięki swojej niedającej się stłumić mocy wzniecania buntu i krytyki oraz dzięki swojej istotowej zdolności do pobudzania krytycznej autorefleksji.

Pomimo różnicy między tonem obecnym u Nafisi oraz u autorek takich jak Hirsi Ali i Manji podstawowy przekaz tego pamiętnika nie jest wcale tak różny: społeczeństwa islamskie są niezdolne do myślenia, refleksji i tworzenia; ich skłonność do przemocy jest najbardziej widoczna w ich sposobie traktowania kobiet. W jednym miejscu Nafisi posuwa się do wygłoszenia radykalnego oświadczenia, że irańskie studentki są zdolne tylko do służalczego schlebiania swoim wykładowcom, ponieważ „,[o]d pierwszego dnia, kiedy znalazły się w szkole podstawowej, mówiono im, by uczyły się na pamięć. Wpajano im przekonanie, że ich opinie się nie liczą" (282). Tego rodzaju twierdzeniom towarzyszą bezpodstawne zdania typu: „Jest powszechnie znana prawda, że muzułmanin, niezależnie od swego majątku, potrzebuje dziewięcioletniej żony dziewicy" (327). Pogarda, którą Nafisi rezerwuje dla Irańczyków i muzułmanów, wyraźnie kontrastuje z uwielbieniem, którym darzy ona Zachód - jego osiagnnięcia kulturalne, jedzenie, język, literaturę, czekoladki i filmy. Możemy teraz dostrzec, że to połączenie odrazy do wszystkiego, co muzułmańskie, z wielkim entuzjazmem wobec wszystkiego, co zachodnie, jest strukturalną cechą tego gatunku.

Taki obraz życia w Iranie jest bezlitośnie wybiórczy. We wspomnianym okresie irański klerykalny reżim stanął przed jednym z największych wyzwań w postaci powszechnego ruchu na rzecz reform, w którym kobiety odgrywały kluczową rolę; co więcej, irańskie uniwersytety znajdowały się w centrum tej transformacji politycznej. Wpisuje się to w długie dzieje zaangażowania irańskich studentów w niemal wszystkie znaczące ruchy protestu w dobie 
nowoczesności, łącznie z obaleniem szacha. Jednym z najbardziej interesujących osiagnięć z ostatnich trzydziestu lat jest pojawienie się prasy feministycznej i krytycznej hermeneutyki świętych tekstów, będącej w świecie muzułmańskim czymś wyjątkowym (Najmabadi 1998). W tym samym okresie, o którym Nafisi pisze z taką pogarda, w Iranie powstawały cieszące się międzynarodowym uznaniem filmy, nie tylko krytyczne wobec wielu aspektów współczesnego irańskiego społeczeństwa, ale i refleksyjnie roztrząsające egzystencjalny wymiar nowoczesnego życia. Żadne z tych osiagnnięć nie przyszło łatwo i nie zaistniałoby bez ceny, jaką musieli zapłacić ci i te, którzy_re walczyli_ły z absolutystycznymi tendencjami obecnymi w klerykalnym reżimie zarządzającym aparatem państwowym Iranu. Należy jednak podkreślić, że sprzeciw pojawił się nie tylko w środowiskach świeckiej lewicy i liberałów, ale również wśród samych duchownych, z których wielu poparło rewolucję u jej początków, ale później stało się najbardziej stanowczymi krytykami korupcji i totalitarnej kontroli charakterystycznych dla reżimu ${ }^{5}$. Innymi słowy, krytyka społeczna i polityczna stała się integralnym aspektem życia w porewolucyjnym Iranie.

Caytajac Lolitę w Teheranie wpasowuje się w paradygmat orientalistyczny: odtwarza i potwierdza wrażenia swoich zachodnich czytelników, nie dostarczając im niespodzianek czy wyzwań, które kazałyby im dostrzec coś innego niż to, co, jak sądzą, już wiedzą na temat Iranu oraz jego bogatej historii kulturalnej i politycznej. Podobnie jak słynny obraz Delacroix Kobiety algierskie, pamiętnik Nafisi upiększa tylko sieć anegdotycznych, pełnych uprzedzeń impresji, które odbiorca wnosi do interpretacji tego przedmiotu. Nie sposób nie zastanawiać się, jakie byłyby losy tej książki, gdyby zaskoczyła ona swoich czytelników faktami niewpasowującymi się tak dobrze w strukturę oczekiwań odbiorców, takimi jak ten, że wskaźnik umiejętności czytania i pisania wśród kobiet za rządów islamistów skoczył z 35,5\% w 1976 roku do 74,2\% w roku 1996; że kobiety stanowia ponad 60\% studentów na irańskich uniwersytetach; że w porewolucyjnym Iranie do parlamentu zostało wybranych więcej kobiet niż w USA (Bahramitash 2006, 235). W dodatku przyrost naturalny w Iranie spadł z 3,2\% w 1980 roku do poziomu $1,2 \% \mathrm{w}$ roku $2001 \mathrm{w}$ wyniku jednej z najbardziej efektywnych inicjatyw z zakresu planowania rodziny i zdrowia publicznego w najnowszej historii. Jeśli irańskie kobiety rzeczywiście mogły wywalczyć sobie taki poziom politycznego i materialnego upodmiotowienia w warunkach rządów islamistów, to co nam to mówi o raczej uproszczonej diagnozie, zgodnie z którą rządy te są i zawsze będą opresyjne wobec kobiet?

Książka Nafisi dobrze wpasowała się w geopolityczne zamiary Białego Domu Busha, który ogłosił, że Iran stanowi część „osi zła”, upubliczniając tym samym neokonserwatywne plany ataku na ten kraj (Hersch 2006). Trudno nie uznać, że Nafisi dostarczyła kulturowego

\footnotetext{
5 Niektórzy spośród tych krytyków to wybitne osobistości takie jak Shariat-Madari, Mahmoud, Taleqani, Abdollah Nouri i Hossein Ali Montazeri. Opis tej formułowanej od wewnątrz krytyki można znaleźć w: Abdo i Lyons 2004.
} 
argumentu na rzecz tych planów, zwłaszcza tych przedstawionych jej przez neokonserwatywny establishment. Po tym, jak Bernard Lewis, orientalistyczny ideolog w służbie współczesnej amerykańskiej imperialnej przygody na Bliskim Wschodzie, nazwał jej książkę „arcydziełem”, Nafisi otrzymała prestiżowa posadę w Johns Hopkins School of Advanced International Studies, miejscu, w którym jej przyjaciel Fouad Ajami, inny prominentny konserwatywny ideolog, kieruje programem studiów bliskowschodnich ${ }^{6}$. Fakt, że przyznano jej to stanowisko mimo braku znaczącego dorobku publikacyjnego czy choćby wcześniejszego zajmowania porównywalnego stanowiska w podobnej instytucji, świadczy o wadze usług, jakich dostarczyła dziedzicom amerykańskiego imperium.

Niezależnie od politycznego patronatu Nafisi jest również promowana jako ikona kultury przez korporacje, które są skore do demonstrowania swojej odpowiedzialności społecznej. Producent luksusowego samochodu Audi promował ja (razem z takimi postaciami medialnymi jak David Bowie czy aktor William H. Macy) w ramach swojej kampanii reklamowej Never Follow [„Nigdy nie podążaj za kimś”] nakierowanej na spopularyzowanie marki u zamożnych i wykształconych konsumentów. Nafisi pojawiła się w reklamach Audi zamieszczonych w pismach tak różnorodnych jak V anity Fair, Wired, Golf Digest, The New Yorker i Vogue (zob. Salamon 2004). Jako że reklamy samochodów nie mają tylko na celu sprzedawanie samochodów, ale także formy społecznej tożsamości, promocja Nafisi przez Audi ukazuje, jak realna troska o życie muzułmanek została opróżniona ze swej krytycznej treści i zredukowana do utowarowionego symbolu snobistycznego szyku. Projekt „ratowania muzułmańskich kobiet” przypomina niegdysiejszą kampanię „Ratujmy wieloryby”; o ile jednak ta druga rzeczywiście mogła jakoś przyczynić się do poprawy życia gatunku, do ochrony którego dążyła, ta pierwsza może, jak się obawiam, z łatwością całkowicie wymazać obiekt, za którym się wstawia.

Konkluzja ta bliska jest ocenie zawartej w druzgocącej recenzji Caytajac Lolitę $w$ Teheranie, pióra Hamida Dabashiego (2006). Krytykuje on, oprócz politycznej instrumentalności tej książki, również jej okładkę, która jest efektem „wizualnego rabunku”. Przedstawia ona dwie młode kobiety w chustach na głowach, z przejęciem pochylone na tekstem, którym, jak ma się domyślać czytelnik, jest Lolita „w Teheranie”. Dabashi dowodzi, że jest to przycięta wersja zdjęcia, które ukazuje dwie uczennice, czytające wiodącą gazetę opozycyjną donosząca o zwycięstwie w wyborach reformistycznego kandydata Chatamiego, którego sukces przypisywano głównie głosom kobiet i młodzieży. Ocenzurowanie fotografii i ogołocenie jej z historycznego kontekstu oznacza, jak twierdzi Dabashi, odarcie tych młodych kobiet „z ich inteligencji i poczucia moralności oraz zaangażowania w demokratyczne dążenia ich kraju, i zamknięcie ich w kolonialnym haremie”. Jego zdaniem, jako że okładka książki umieszcza

\footnotetext{
${ }^{6}$ Fouad Ajami zmarł w 2014 roku [przyp. tłum.].
} 
owe dziewczyny w kontekście słynnej powieści Nabokova opowiadającej o pedofilii, odtwarza ona starą orientalistyczną fantazję na temat „kazirodczego” charakteru Wschodu, w swej istocie zarazem odrażającego i kuszącego. Trudno uniknąć wniosku, że indywidualność kobiet, których cierpienie chce opisać Nafisi, musi zostać wymazana, zarówno w sensie narracyjnym, jak i wizualnym, aby mogły one zostać uświęcone jako „uwięzione dziewice”, ofiary przemocy islamu. Fakt, że książka ta zyskała uznanie pisarek feministycznych takich jak Susan Sontag i Margaret Atwood, jest niepokojący, pokazuje bowiem, że nawet zdecydowane krytyczki konserwatyzmu dominującego obecnie w Europie i USA pozostają ślepe na niebezpieczne pominięcia, których pełne są teksty takie jak książka Nafisi, oraz na fakt, że ułatwiają one wdrażanie szerszego projektu politycznego ${ }^{7}$. Niezwykle ważne jest to, by autorki feministyczne i krytyczki kultury nauczyły się czytać takie teksty bardziej krytycznie, uwzględniając złożoność i dwuznaczności, które towarzyszą pogardzanemu powszechnie klerykalnemu reżimowi irańskiemu, a także obudzonej przez niego polityce sprzeciwu.

\section{Ale co z prześladowaniem kobiet w islamie?}

Można by w tym miejscu zaprotestować i stwierdzić, że choć opowieści o cierpieniu muzułmanek są wykorzystywane do celów politycznych, nie zmienia to faktu, iż w społeczeństwach islamskich rzeczywiście mamy do czynienia z cała gamą odrażających, mizoginicznych praktyk. Czy ktokolwiek troszczący się o los kobiet może nie krytykować i nie potępiać tych niewypowiedzianych okropności? Swoją odpowiedź zacznę od kategorycznego stwierdzenia, że uznaję, iż kobiety w społeczeństwach muzułmańskich faktycznie cierpią $z$ powodu nierównego traktowania i sa narażone na wynikające $z$ tej nierówności akty przemocy. Każda feministka i feminista chcąca_y poprawić los muzułmańskich kobiet musi jednak wyjść nie tyle od listy nadużyć islamu, ale od kontekstów, w których te akty przemocy uznawane sa za warte oprotestowania, przez kogo, w jakich warunkach i w jakim celu.

Rozwijając ten argument, chciałabym przyjrzeć się szeroko nagłaśnianej kwestii „zabójstw honorowych”, powszechnie potępianej praktyce, której międzynarodowe media poświęcały uwage jeszcze przed wydarzeniami z 11 września, a która w bardziej dramatycznych ujęciach pojawiła się w omawianej tu przeze mnie literaturze. „Zabójstwa honorowe” uznaje się powszechnie za „praktykę islamską”, polegająca na tym, że kobiety podejrzane

\footnotetext{
${ }^{7}$ Susan Sontag na przykład chwali Nafisi w ten sposób: ,jestem zafascynowana i poruszona opowieścią Azar Nafisi o tym, jak sprzeciwiała się ona i jak pomagała innym sprzeciwiać się wojnie z kobietami prowadzonej przez radykalny islam. Jej pamiętnik zawiera ważne i należycie pogłębione refleksje na temat spustoszeń czynionych przez teokrację, na temat myślenia i ciężkich prób związanych z wolnością - jak również porywający opis przyjemności i rozwoju świadomości płynących ze spotkań z wielką literaturą i błyskotliwą nauczycielką". Zob. stronę internetowa wydawnictwa Random House: www.randomhouse.com/acmart/catalog/ display.pperl?isbn=9780812971064 (dostęp: 4.09.2006).
} 
o podejmowanie zakazanych zachowań seksualnych są mordowane przez mężczyzn z ich rodziny. Praktykę tę można jednak porównać z częstymi w społeczeństwach zachodnich przypadkami mordowania kobiet przez mężczyzn. Przyjrzyjmy się na przykład takim statystykom: wiele raportów pokazuje, że w Pakistanie, kraju liczącym 140 milionów obywateli, zabijanych jest 1000 kobiet rocznie (w Pakistanie, obok Jordanii, odnotowuje się najwyższy wskaźnik „zabójstw honorowych”) ${ }^{8}$. Family Violence Prevention Project [Projekt na rzecz Przeciwdziałania Przemocy w Rodzinie] podaje z kolei, że w USA, kraju o populacji liczącej 280 milionów, corocznie około 1500 kobiet zostaje zamordowanych przez swoich mężów albo partnerów w ramach tego, co nazywa się „zbrodnią z namiętności” (w USA codziennie giną ponad trzy kobiety, zabite przez swoich chłopaków czy mężów) ${ }^{9}$. Mimo porównywalności tych statystyk „zabójstwa honorowe” rzadko omawia się porównując obydwa te konteksty. W większości omówień konstruuje się raczej „zabójstwo honorowe” jako symptomatyczne dla „kultury islamskiej” (wymowne jest przy tym zrównanie ze sobą religii i kultury), podczas gdy zabójstwa kobiet dokonywane przez mężczyzn w USA przedstawia się jako przypadki indywidualnej patologii albo nadmiaru namiętności. Zgodnie z tą logiką amerykańscy mężczyźni działają motywowani zazdrościa (emocja „,naturalna”) o swoich seksualnych rywali (choć trochę ich przy tym ponosi), podczas gdy muzułmańscy mężczyźni działaja determinowani przez swoja „kulturę”, irracjonalnie i ślepo odtwarzając mizoginiczne zwyczaje i tradycje. Innymi słowy, zindywidualizowane ujęcie przemocy domowej w USA zostaje ugruntowane poprzez kontrast z tautologicznym ujęciem „,kultury islamskiej”. Z założenia tego wynika, że odpowiednią strategią zwalczania tej formy przemocy na Zachodzie jest zmienianie zachowań jednostek, natomiast w społeczeństwach muzułmańskich należy zreformować, jeśli nie w ogóle zlikwidować, „kulturę islamską”. Takie ujęcie, ze swym dążeniem do mierzenia i ważenia seksizmu (zachodni waży mniej; islamski waży więcej), pomija fakt, że obie formy przemocy są w równym stopniu wytworem kultury, jak również płci kulturowej; obie zależą od swoistych sposobów wartościowania kwestii podporządkowania kobiet, seksualności, stosunków pokrewieństwa i różnych form męskiej przemocy. Każdy sprzeciw wobec tych odmiennych (choć porównywalnych) aktów męskiej przemocy wymaga dokładnego i popartego dowodami zrozumienia relacji społecznych i gramatyki kulturowej, które nadają im znaczenie i wagę.

Moja teza jest dość prosta i jasna: żaden obiekt dyskursywny nie pozostaje w prostym związku z rzeczywistościa, do której ma się odnosić. Reprezentacja faktów, przedmiotów i wydarzeń jest zapośredniczona przez pola władzy, w których te reprezentacje krążą i dzięki którym nabierają konkretnego kształtu. W związku z tym współczesna troska o muzułmanki

\footnotetext{
${ }^{8}$ Zob. www./hrcp-web.org/women.cfm\# (dostęp: 9.03.2007) i raport Amnesty International opublikowany we wrześniu 1999 roku na stronie: www.amnesty.org/library/Index/engASA330181999 (dostęp: 9.03.2007).

${ }^{9}$ Zob. stronę Family Violence Prevention Project: www.endabuse.org/resources/facts.
} 
jest w paradoksalny sposób powiązana z, i ukształtowana przez, dyskurs cywilizacyjny określający formę spotkania Euro-Ameryki z islamem. Feministyczny wkład w demonizację islamu ani w żaden sposób nie pomaga muzułmańskim kobietom, ani nie sprzyja dążeniu do wprowadzenia genderowej sprawiedliwości. Odtwarza raczej i umacnia kulturowy oraz cywilizacyjny rozłam stanowiący - w obecnym, tragicznym momencie historycznym - podporę nie tylko dla polityki konserwatywnej, ale i liberalnej.

\section{Kobiety, demokracja i wolność}

W ostatnich dwóch częściach tekstu chciałabym przeanalizować rolę, jaką retoryka demokracji i wolności odegrała w uzasadnieniu „wojny z terroryzmem”; szczególną uwagę zwrócę przy tym na świeckość tej retoryki i konstytutywne dla niej założenia. Nawet najbardziej pobieżny rzut oka na obecny dyskurs medialny pozwala stwierdzić, że zarówno postępowi, jak i konserwatywni stratedzy zgadzają się co do tego, iż najlepszym sposobem na wyeliminowanie islamskiego fundamentalizmu jest wzmocnienie sprawczości kobiet poprzez umożliwienie im kształcenia się i zapewnienie dostępu do zasobów ekonomicznych oraz reprezentacji politycznej. Jak ujmuje to dziennikarka New York Timesa, Barbara Crossette (2001): „kiedy umacnia się wpływ kobiet [...], umacnia się też umiarkowane centrum, co przyczynia się do stabilizacji gospodarczej i demokratyzacji”. Potoczny pogląd głosi, że o ile feminizm stanowi „przeciwieństwo fundamentalizmu” (Pollitt 2002, xiv), a fundamentaliści nienawidza przecież demokracji, wzmocnienie pozycji kobiet doprowadzi do umocnienia się feminizmu, który z kolei przyczyni się do eliminacji islamskiego fundamentalizmu.

Pomijając już niejednoznaczny fakt, zgodnie z którym wiele ruchów islamistycznych określanych w cytowanych przeze mnie tekstach jako fundamentalistyczne - raczej poszerza spektrum politycznej debaty w świecie muzułmańskim, niż ją zawęża, chciałabym zakwestionować upraszczające powiązanie demokracji i statusu społeczno-ekonomicznego kobiet: ideę, że poprawa sytuacji kobiet automatycznie doprowadzi do demokratyzacji. Powiązanie to możemy w prosty sposób zweryfikować, jeśli przyjrzymy się warunkom życia kobiet w Iraku przed pierwszą inwazją amerykańską na ten kraj w 1990 roku. Mimo faktu, że Irak pod rządami Saddama Husajna nie był demokratyczny, irackie kobiety cieszyły się jednym z najwyższych współczynników piśmienności w Trzecim Świecie i były szeroko reprezentowane $\mathrm{w}$ wielu zawodach, łącznie $\mathrm{z}$ armią $\mathrm{i}$ urzędami państwowymi. U szczytu koniunktury gospodarczej Iraku Husajn wprowadził wiele rozwiązań politycznych, które miały zachęcić kobiety do podejmowania pracy zarobkowej, takich jak dobrze opłacane urlopy macierzyńskie, równe płace i świadczenia oraz darmową wyższą edukację (Chew 2005; Bahdi 2002). Pod tym względem Irak nie różnił się od wielu krajów socjalistycznych (takich jak Kuba, dawny Związek Radziecki czy państwa Europy Wschodniej), w których nieobecność 
demokracji liberalnej nie przekładała się wcale na marginalizację kobiet w życiu społecznogospodarczym i politycznym.

Sytuacja irackich kobiet pogorszyła się po wojnie irańsko-irackiej z lat 1980- 1988, ale najpoważniejszy regres miał miejsce po Wojnie w Zatoce (1990-1991) wskutek sankcji gospodarczych nałożonych przez USA w porozumieniu z ONZ i ich europejskimi sojusznikami. Wskaźnik piśmienności wśród kobiet obniżył się gwałtownie po Wojnie w Zatoce, a dostęp irackich kobiet do edukacji, środków transportu i miejsc pracy stawał się coraz trudniejszy. Obecna okupacja Iraku przez USA to tylko najnowszy etap dwunastoletniego okresu obowiązywania druzgocących sankcji, które bezpośrednio przyczyniły się do dramatycznego pogorszenia warunków życia kobiet w tym kraju. Oczywiście obecna sytuacja, z powszechną przemoca, chaosem i zastojem gospodarczym sprawia, że kobiety (a także osoby starsze, dzieci i niepełnosprawni) stają się najsłabszymi ofiarami społecznego bezładu, a w możliwej do przewidzenia przyszłości nie doświadczą raczej ani odrobiny porządku. Ta utrata „życia i wolności” przez irackie kobiety nie wzbudziła jednak u Europejczyków i Amerykanów takiego samego oburzenia, jak pojedyncze opowieści o cierpieniu kobiet pod kuratela islamu; na dodatek wielu ekspertów medialnych sugeruje obecnie, że wdrażanie demokracji przedstawicielskiej na Bliskim Wschodzie nie jest być może aż tak dobrym pomysłem, skoro wybory moga dać władzę islamistycznym partiom politycznym (co rzeczywiście miało miejsce w przypadku wyborów w Palestynie i Egipcie w 2005 roku) (Feldman 2006; Friedman 2006). Niezależnie od faktu, że komentatorzy ci uznają zdobycie władzy politycznej przez islamistów za niekorzystne dla interesów amerykańskich, los kobiet w reżimach islamistycznych przywołuje się często jako główny powód uzasadniający wysiłki, które mają na celu udaremnienie sukcesu islamistów w wyborach. Zwróćmy uwagę na to, że po raz kolejny uznaje się tu euroamerykańskie interesy strategiczne i dobro kobiet za równoważne; zakłada się równoważność demokracji (zdefiniowanej wąsko w kategoriach wyborów) i statusu kobiet.

Jeden z bardziej poruszających apeli o wdrożenie demokracji za pośrednictwem ustawowego zadekretowania wolności kobiet wystosowała Barbara Ehrenreich w komentarzu dla New York Timesa w okresie poprzedzającym wybory prezydenckie w 2004 roku. W tekście tym autorka uznaje pamiętniki Carmen bin Laden, Rozdarty czarczaf, za manifest, którym wszyscy Demokraci powinni się inspirować w swoim podejściu do świata muzułmańskiego. Jak wspomniałam wcześniej, jest to historia pełnego luksusów życia, jakie Carmen prowadziła zarówno w Szwajcarii, gdzie się wychowywała i gdzie obecnie mieszka, jak i w Arabii Saudyjskiej, gdzie przez wiele lat żyła jako jedyna żona jednego z bogatych dziedziców rodziny bin Laden. Większa część książki opisuje klaustrofobiczne życie w Arabii Saudyjskiej przerywane przez długie, pełne przepychu wakacje w Europie, pałace z zastępami służby i wystawne przyjęcia. Carmen, podobnie jak inne wspominane przeze mnie autorki, jest pełna 
uwielbienia dla Zachodu, jego stylu życia i „możliwości”. Jej entuzjazmowi wobec zachodniego stylu życia dorównuje tylko kpina i lekceważenie wobec saudyjskich kobiet. Według niej gorset tradycji kulturowych skazuje je na mentalność stadną: „Na Bliskim Wschodzie człowiek nigdy nie rozwija się jako jednostka. Ludzie tylko na krótko zdołają uciec od swojej tradycji, ale potem reguły ich doganiają" (23).

Ta właśnie narracja zainspirowała Barbarę Ehrenreich do wezwania kandydata Demokratów na prezydenta, Johna Kerry’ego, aby uczynił równość płci głównym punktem strategii politycznej na Bliskim Wschodzie, ponieważ jej zdaniem głównym wrogiem [Zachodu] jest nie terroryzm, ale „ekstremistyczna rebelia islamistyczna, której siła bierze się z jej roszczenia do reprezentowania muzułmańskich mas wobec prześladującej je władzy”. Ehrenreich błędnie, choć przewidywalnie, redukuje różnorodność ruchów islamistycznych do tych w rodzaju organizacji dowodzonej przez Osamę bin Ladena; dlatego też traktuje praktykę zasłaniania głowy i/lub twarzy (tak powszechną obecnie w wielu obszarach świata muzułmańskiego) wyłącznie jako dowód uwikłania muzułmańskich kobiet w patriarchalna ideologię. Jak wykazało wielu naukowców w ciagu ostatnich 15 lat, ruchy islamistyczne, inaczej niż sądzi Ehrenreich, są nie tylko różnorodne, ale także mają silne poparcie wśród kobiet, które są odpowiedzialne za większość pracy społecznej wykonywanej w najważniejszych z tych ruchów (Abdo 2004; Deeb 2006; Mahmood 2005). Zamiast ograniczać wolność kobiet, ruchy islamistyczne często umożliwiają im uczestnictwo w społeczno-politycznym życiu ich społeczeństw. Argumentacja Ehrenreich pomija złożone przesunięcia, wyzwania i transformacje polityczne, które dokonały się za sprawą tych ruchów i które nie wpisują się w uproszczoną logikę patriarchalnego podporządkowania i polityki autorytarnej.

Fakt, że promowany przez Carmen bin Laden wzór białej, elitarnej, burżuazyjnej kobiecości stał się symbolem tej wizji „demokracji”, powinien uwrażliwić nas na jej imperialistyczne podłoże. Brutalna i bezlitosna wobec form uspołecznienia i podmiotowości, które chce przerobić na swój wzór, wizja ta oferuje tylko kpinę i pogardę kobietom niedostosowującym swoich pragnień i celów do liberalnego stylu życia. Właśnie z racji pewności Ehrenreich co do tego, że owe rebelianckie pragnienia nie leżą w interesie kobiet, może ona wyciąnnąć wniosek, iż zadaniem USA (oczywiście rządzonych przez Demokratów, nie zaś Republikanów) jest wyzwolenie tych zniewolonych stworzeń. Ów misjonarski zapał do przerabiania „kultury i cywilizacji” bardzo przypomina kolonialne projekty z dziewiętnastego i początku dwudziestego wieku, kiedy to europejskie potęgi, również motywowane oburzeniem wobec tego, co uznawały za ucisk kobiet w islamie, chciały ucywilizować miejscowe populacje za pomoca reform kulturalnych i edukacyjnych. Wprowadzone przez Brytyjczyków regulacje i kontrole praktyk palenia wdów (sati) w Indiach oraz okaleczania kobiecych genitaliów w Sudanie, praktyk będących symbolami barbarzyńskiego traktowania kobiet w tych skolonizowanych kulturach, rzadko miały korzystne konsekwencje dla tych, o których ochronę 
rzekomo chodziło. Jak zauważa Lata Mani, tubylcze kobiety nie były ani podmiotami, ani przedmiotami tych reform, ale terenem, na którym rozgrywała się toczona przez Europejczyków i miejscowych bitwa o wizję imperium oraz nowoczesności (Boddy 2007; Mahmood 2005, zwł. rozdział 1 i epilog).

\section{Sekularyzm i imperium}

Postulaty sekularyzacji i liberalizacji islamu, w wyniku których muzułmanie mogliby zacząć wieść bardziej oświecony żywot, wypowiadane są obecnie z różnych pozycji, zarówno prawicowych, jak i lewicowych. Wezwania te spotykają się z pozytywną reakcja świeckich feministek (o rożnych poglądach politycznych), przekonanych od dawna, że to religia jest źródłem ucisku kobiet. Wiele liberalnych feministek, krytycznych wobec neokonserwatywnej bojowości, opowiada się za szeroko zakrojoną strategia powolnej, stopniowej transformacji, dzięki której, jak ujmuje to Katha Pollitt, „zorganizowana religia miałaby zaniknać, a przynajmniej odejść od dogmatyzmu, autorytarności i reakcji w stronę nieokreślonego, życzliwego, ponadwyznaniowego doskonalenia duchowego, które jeśli łączyłoby się z jaką́s polityka, byłaby to polityka liberalna” (2002, ix). Ta pozornie niegroźna wizja zakłada świecka koncepcję religijności, zgodnie z którą religię traktuje się jako prywatny system przekonań, ujęty w formę zestawu tez, które dana jednostka uznaje za swoje. Sekularyzm, redukowany często do swojej głównej zasady doktrynalnej (rozdzielenie religii i państwa), działa tu jako projekt społeczno-kulturowy legitymizujący sprywatyzowaną formę religijnej podmiotowości, która zawdzięcza swoje istnienie suwerennemu państwu (nie zaś tradycyjnej władzy religijnej). Co istotne, protagonistką ożywiającą ten świecki, liberalny model religijności jest autonomiczna jednostka, samodzielny podmiot, który może cenić duchowe prawdy zawarte w tradycji religijnej, ale jest na tyle oświecony, by rozumieć, że prawdy te nie mają na tym świecie żadnej epistemologicznej czy politycznej siły. Te aspekty świeckiej kultury, podkreślane obecnie w ramach kategorii świeckości, sa promowane nie tylko przez państwo, ale także przez wiele innych społecznych aktorów i organizacji, nierzadko krytycznych wobec różnych strategii i uprawnień państwa ${ }^{10}$.

Ta świecka koncepcja religijności, widoczna w powyższej wypowiedzi Kathy Pollitt, zawiera szereg założeń dotyczących autonomii i wolności, współgrających z liberalną myśla feministyczna. Najbardziej oczywiste $z$ nich to potężna figura autonomicznej jednostki zdolnej do realizowania własnych pragnień pod nieobecność transcendentnej woli, tradycji czy obyczaju - która nadal ożywia liczne projekty feministyczne, pomimo wielu

\footnotetext{
${ }^{10}$ Niedawne opracowania naukowe traktujące sekularyzm nie tyle jako porzucenie religii, co jej określone przekształcenie to m.in:. Asad 2003; Mahmood 2006.
} 
bezkompromisowych filozoficznych i antropologicznych krytyk tej ograniczonej koncepcji podmiotu (zob. Butler 1993; Mahmood 2005, rozdział 1). Drugim założeniem kluczowym dla tej zeświecczonej wizji religijności jest pogląd, że zewnętrzne formy religii - liturgia, rytuały i święte teksty - są nieistotne dla uniwersalnej prawdy, jaką wyrażają. Określona postać, jaką przyjmuja pisma i rytualne praktyki, jest, innymi słowy, postrzegana jako pozbawiona znaczenia dla duchowości (niematerialnej i transcendentnej), której ma być substytutem.

Owo sekularystyczne ujęcie praktyk rytualnych sprawia, że większość świeckich feministek ma trudności ze zrozumieniem stanowiska wielu kobiet muzułmańskich, twierdzących, że zasłona jest wymogiem doktrynalnym. Kobiety uznające, że noszenie chusty stanowi część obowiązków religijnych, boskie przykazanie czy formę praktyki etycznej, są zwykle traktowane jak ofiary fałszywej świadomości, skrępowane tradycjonalizmem każącym im uwewnętrzniać poglądy mizoginicznych uczonych w piśmie, których twierdzeniom powinny stawiać opór ${ }^{11}$. Chusta - redukowana albo do swojego znaczenia symbolicznego (symbolu tożsamości muzułmańskiej albo ucisku kobiet), albo do funkcjonalności (chusta chroni kobiety przed molestowaniem seksualnym) - rzadko traktowana jest jako wyraz i sposób poddania muzułmanki woli Boga, mimo licznych świadectw, zgodnie z którymi takie rozumienie chusty jest najważniejsze dla wielu noszących ją kobiet (Mahmood 2005; Fernando 2006; Scott 2007). Poważne potraktowanie ich słów wymagałoby przekroczenia prostej opozycji między wolnością i podporządkowaniem, budowanej przez liberalizm, i przyjrzenia się formom podporządkowania nieodłącznym od konkretnego sposobu konstruowania wolności oraz systemowi nierówności płci, w ramach którego ten konstrukt funkcjonuje. Niestety, euroamerykańska debata publiczna zmierza w zupełnie innym kierunku (co unaocznia francuski zakaz noszenia chust i podejmowane przez inne kraje próby wprowadzenia podobnych ustaw). Współczesne wezwania do reformy islamu opierają się na wąskiej wizji zsekularyzowanej religijności, lezącej u podstaw wielu liberalnych założeń określających, co oznacza bycie człowiekiem.

Problematyczność tej normatywnej wizji zsekularyzowanej religijności polega na jej partykularności, połączonej z przeświadczeniami, które nie dopuszczają sporów i nie pozwalają na otwartość wobec innych - pod względem religijnym czy politycznym - sposobów życia. Telos liberalno-demokratycznego, protestanckiego społeczeństwa (którego etos kondensuje się w kosmopolitycznej wrażliwości i przyjemnościach jego oświeconych obywateli) zostaje ustanowiony jako Mekka, do której muzułmanie powinni sumiennie zmierzać. Niezależnie od

\footnotetext{
${ }^{11}$ Nawal El-Saadawi (2004), słynna egipska świecka feministka, wyraziła ten pogląd, komentując transparent niesiony przez francuskie muzułmanki protestujące przeciwko wprowadzonemu niedawno zakazowi noszenia chust: „chusta to przykazanie, nie symbol”. Saadawi uznała to hasło za wyraz fałszywej świadomości protestujących kobiet, oznakę ich naiwnej współpracy z kapitalistycznym spiskiem mającym na celu uniemożliwienie światu muzułmańskiemu zdobycia „prawdziwej świadomości politycznej”. Po raz kolejny poważne traktowanie doktryny religijnej postrzegane jest jako coś, co może tylko skrywać materialną władzę.
} 
niewykonalności i partykularności tego planu, tym, co w nim najbardziej imperialistyczne, jest łańcuch ekwiwalencji, na którym się on wspiera. Przedmiotem tego bezlitosnego nakazu są nie tylko islamistyczni działacze, ale wszyscy muzułmanie kierujący się rzekomo nieliberalnymi, ortodoksyjnymi i konserwatywnymi interpretacjami islamu, przede wszystkim przykazaniem noszenia chusty czy wymogami ścisłego przestrzegania rytuałów, unikania swobodnego mieszania się płci oraz rozstrzygania publicznych i politycznych kwestii spornych poprzez argumentacje natury religijnej. Jako że zarzut fundamentalizmu dotyczy teraz nie tylko zaangażowanych islamistów, ale wszystkich przywiązanych do tego typu praktyk, wezwania do liberalizacji islamu zmierzają do transformacji również tych muzułmanów, których styl życia ma stać się tymczasowy i warunkowy, jeśli nie skazany na zagładę, za sprawą procesu stopniowych, lecz nieuniknionych reform.

Jak dowodzę w innym miejscu (Mahmood 2006), normatywny wymiar liberalnego projektu nie ma charakteru wyłącznie retorycznego. Cieszy się on poparciem amerykańskiego Departamentu Stanu, który niedawno przeznaczył 1,3 miliarda dolarów na inicjatywę nazwaną Muslim World Outreach [„Pomoc Muzułmanom Świata”] z zamiarem przekształcenia serc oraz umysłów muzułmanów i muzułmanek za pośrednictwem szeregu programów teologicznych, kulturalnych i pedagogicznych. Inicjatywa ta jest częścią szerszej strategii Rady Bezpieczeństwa Narodowego Białego Domu, która ma na celu kształcenie duchownych muzułmańskich i zakładanie szkół religijnych propagujących liberalne interpretacje islamu, reformę programów szkół państwowych i produkcję mediów (co obejmuje zakładanie stacji radiowych i telewizyjnych, produkcję i dystrybucje islamskich programów typu talk show oraz ogólnie kształtowanie treści publicznej debaty na tematy religijne w obrębie istniejących już mediów w krajach muzułmańskich). Trzeba podkreślić, że obiektem tej wielostronnej strategii nie sa już zaangażowani islamiści, ale zwyczajni, „tradycyjni” muzułmanie i muzułmanki, których postrzega się jako w przygnębiający sposób pozbawionych świeckiej wrażliwości wymaganej od nowoczesnych podmiotów ${ }^{12}$. Projekt ten jest pod wieloma względami podobny do zimnowojennej strategii Departamentu Stanu - z jednym wyjątkiem: obecna kampania ma jawne cele teologiczne, unieważniające główną liberalną zasadę - prawo do wyznawania religii i poszanowanie wolności sumienia - którą USA ma rzekomo upowszechniać wśród muzułmanów za pośrednictwem tej kampanii. Owa podjęta przez Amerykanów próba organizowania reform w świecie muzułmańskim zawiera liczne paradoksy, ale tym, na co należy zwrócić szczególną uwage, jest sposób, w jaki strategia promowania liberalnej religijności na Bliskim Wschodzie towarzyszy prowadzonej przez Biały Dom Busha aktywnej promocji konkretnej postaci ewangelikalnego chrześcijaństwa u siebie. Jak argumentuję gdzie indziej,

\footnotetext{
12 Długa listę powodów, dla których tradycjonalistyczni muzułmanie stanowią zagrożenie dla interesów strategicznych USA, można znaleźć w: Benard 2003.
} 
owe pozornie przeciwstawne tendencje należy analizować jako różne aspekty współczesnego sekularyzmu - pamiętając, że sekularyzm nie polega po prostu na usunięciu religii z polityki, ale na odmiennej organizacji stosunków między nimi.

Co więcej, wcale nie jest dla mnie oczywiste to, że upowszechnienie wśród muzułmanów liberalnej wrażliwości religijnej z konieczności zmniejszy liczbę ataków na USA czy państwa europejskie. Nie dlatego, że muzułmanie są z natury skłonni do przemocy, ale dlatego, że ich pretensje do Zachodu są związane z geopolitycznymi dysproporcjami władzy i przywilejów. Nawet Osama bin Laden ujął to jasno w przemówieniu z czasu ataku na World Trade Center: żądał wycofania się wojsk amerykańskich z Arabii Saudyjskiej, sprawiedliwego rozstrzygnięcia konfliktu między Izraelem i Palestyną oraz położenia kresu euroamerykańskiej kontroli nad muzułmańskimi zasobami i ziemią. Postulaty te - nawet jeśli nie stosowane przez bin Ladena środki - sa przekonujące dla wielu Arabów i muzułmanów, będących dziś świadkami jednego z najbardziej bezwstydnych imperialnych projektów w nowoczesnej historii, projektu, który jak stwierdza wielu komentatorów - robi więcej dla intensyfikacji walki niż dla jej wyeliminowania.

Program Muslim World Outreach ma na celu tworzenie sojuszy z tymi, których określa się w jego ramach jako „umiarkowanych” uczonych muzułmańskich, głoszących liberalną interpretacje islamu i naśladujących wizję roztaczaną przez tę właśnie inicjatywę amerykańskiego Departamentu Stanu. Fakt, że postulat liberalizacji islamu wysuwa obecnie coraz większa grupa wybitnych intelektualistów muzułmańskich - między innymi Khaled Abul Fadl, Nasr Hamid Abu Zayd, Abdolkarim Soroush i Hasan Hanafi - jest świadectwem hegemonii sprawowanej przez liberalizm, będący ideałem politycznym dla wielu współczesnych muzułmanów. Hegemonia ta odzwierciedla, jak twierdzę, ogromna dysproporcję sił między Euro-Ameryką i krajami muzułmańskimi. W refleksjach tych intelektualistów to islam musi udowadniać swoją zgodność z ideałami liberalnymi; kierunek zadawania pytań nigdy nie zostaje odwrócony. Nie pytają oni na przykład, co oznaczałoby poważne potraktowanie ortodoksyjnych praktyk islamskich, akceptowanych obecnie przez wiele osób w świecie muzułmańskim, i przemyślenie w ich świetle niektórych świeckich, liberalnych wartości, których dziś tak sztywno się trzymamy, takich jak wolność wyboru, autonomia i obojętność wobec religijnych form przynależności. Jak mógłby wyglądać taki dialog? Jak taka rozmowa mogłaby zmienić nasze praktyki wytwarzania wspólnego świata?

Wielu krytyków liberalizmu wskazuje, że dla myśli liberalnej (obejmującej dziś zarówno projekty konserwatywne, jak i radykalne) typowe jest wchłanianie nieznanych form życia w obręb własnej wizji przyszłości, która definiowana jest jako rozwinięcie samej tej liberalnej wizji. Wszystkie formy życia niezgadzające się z nią muszą zostać podporządkowane teleologicznemu procesowi doskonalenia, a następnie wyginą́ lub tymczasowo przetrwać jako forma przejściowa. To podejście do różnicy wydaje się przenikać nie tylko wezwania do 
reformy islamu, ale i wiele nurtów współczesnego feminizmu - szczególnie jeśli idzie o jego pewność, że uczucia i wybory kobiet, zwłaszcza te, które wydają się paradoksalnie tak szkodliwe dla ich interesów, muszą zostać przekształcone dla ich własnego dobra. Chcę tutaj zakwestionować właśnie tę arogancką pewność. Czy nie należałoby zderzyć przeświadczenia o słuszności naszej feministycznej wizji politycznej z odpowiedzialnością za zniszczenie danego sposobu życia w imię tego, by nauczyć „nieoświecone” kobiety, jak mają żyć w bardziej „wolny” sposób? Czy naprawdę rozumiemy formy życia, które tak bardzo chcemy przekształcać w imię tego, by muzułmanie i muzułmanki wiedli bardziej oświeconą egzystencję? Czy potrafimy wziąć pod uwagę możliwość, że praktyki takie jak noszenie chusty mogą oznaczać coś innego niż tylko ucisk i/albo wolność kobiet? Czy straciłyśmy zdolność słyszenia głosów muzułmańskich kobiet, które nie wpasowują się w schemat wyznaczony przez Ayaan Hirsi Ali, Azar Nafisi i Irshad Manji? Czy dogłębna wiedza na temat światów odrębnych, a nawet przeciwstawiających się naszemu kosmopolitycznemu stylowi życia, mogłaby skłonić nas do zakwestionowania nieomylności, z jaką wyrokujemy, co jest dobre dla całej ludzkości? W czasach, gdy polityce feministycznej i demokratycznej grozi, że zostanie zredukowana do retorycznych gestów nagłaśniania nadużyć islamu, pytania te dają pewną małą nadzieję, że dialog ponad religijnymi i politycznymi podziałami - nawet tymi nieprzekraczalnymi zaowocuje wizja koegzystencji, która nie będzie wymagać skazywania całych światów na wymarcie czy tymczasowość. Wymaga to od nas wzięcia pod uwagę możliwości (co być może jest żądaniem zbyt wygórowanym w obecnym imperialnym klimacie), że nie zawsze wiemy, czemu się sprzeciwiamy, i że polityczna wizja musi nieraz uznać własną skończoność, by móc w ogóle pojąć, czym jest to, wobec czego oponuje.

Powstanie tego artykutu nie bytoby mo:̨liwe, gdyby nie wsparcie, którego udrielili mi Noab Salomon, Michael Allan, Stacey May i Mark McGrath. Jestem wdrieczna nie tylko za ich pomoc w znalezieniu materiatu

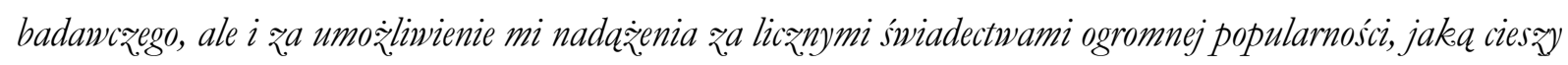
sie omawiany tu gatunek literatury na wielu forach publicznych. Driekeuje Jane Collier, Charlesowi Hirschkindowi i Joan Scott za uwagi krytyczne, a Mayanthi Fernando za zapoznanie mnie z francuskimi prayketadami literatury należacej do tego gatunku. Tesy artykutu prezentowatam w Centrum Studiów Środkowowschodnich Uniwersytetu Kalifornijskiego w Berkeley orazpodczas spotkania z grupa pracownikón Instytutu Badawczego Nauk Humanistycznych na Uniwersytecie Kalifornijskim wiosna 2006 roku. W obydwu praypadkach jestem wdzięrna stuchaczkom i stuchaczom za ich sugestie i uwagi. Dlü̇sza wersja niniejszego artykutu znajduje sie w: Women's Studies on Edge. Red. Joan Scott. Durbam: Duke University Press 2007. Driekeuje Duke University Press za udrielenie mi pozwolenia na powtórna publikacje tekstu w obecnej wersji. 


\section{Wykaz literatury}

Abdo, Genieve. 2004. No God but God: Egypt and the Triumph of Islam. New York: Oxford University Press.

Abdo, Genieve i Jonathan Lyons. 2004. Answering Only to God: Faith and Freedom in Twenty-First Century Iran. New York: Henry Holt.

Ahmed, Leila. 1992. Women and Gender in Islam: Historical Roots of a Modern Debate. New Haven: Yale University Press.

Alam, Fareena. 2006. “Enemy of Faith”. New Statesman July 24: 54-55.

Alloula, Malek. 1986. The Colonial Harem. Minneapolis: University of Minnesota Press.

Amara, Fadela. 2004. Ni putes ni soumises. Paris: La Découverte.

Amara, Fadela i Mohammed Abdi. 2006. Ni putes ni soumises, le combat continue. Paris: Seuil.

Asad, Talal. 2003. Formations of the Secular: Christianity, Islam, Modernity. Stanford: Stanford University Press.

Atwood, Margaret. 2003. “A Book Lover's Tale: A Literary Life Raft on Iran’s Fundamentalist Sea”. Amnesty International Magazine Fall 2003. www.amnestyusa.org/magazine/fall_2003/book_lover/ (dostęp: 7.03.2007).

Bahdi, Reem. 2002. "Iraq, Sanctions, and Security: A Critique”. Duke Journal of Gender, Law, and Policy 9(1): 237-252.

Bahramitash, Roksana. 2006. "The War on Terror, Feminist Orientalism, and Oriental Feminism: Case Studies of Two North American Bestsellers". Critique: Critical Middle Eastern Studies 14(2): 223-237.

Benard, Cheryl. 2003. Civil Democratic Islam: Partners, Resources, Strategies. Pittsburgh: Rand Corporation.

Bin Ladin, Carmen. 2004. Rozdarty czarczaf: moje sycie w Arabii Sandyjskiej. Tłum. G. Jurgut i M. Jurgut. Katowice-Chorzów: Videograf II.

Boddy, Janice. 2007. Civilizing Women: British Crusades in Colonial Sudan. Princeton: Princeton University Press.

Butler, Judith. 1993. Bodies That Matter: On The Discursive Limits of "Sex". New York: Routledge.

Chew, Huibin Amee. 2005. “Occupation Is Not (Women’s) Liberation”. Znet March 24. www.zmag.org/content/showarticle.cfm?ItemID=7518 (dostęp: 26.08.2006).

Crossette, Barbara. 2001. "Living in a World without Women". New York Times November 4: 4.1 .

Dabashi, Hamid. 2006. "Native Informers and the Making of the American Empire". AlAbram Weekly July 1-7. www.mltoday.com/Pages/Commentary/Dabashi-Native Informers.html (dostęp: 24.08.2006).

Deeb, Lara. 2006. The Pious Modern. Princeton: Princeton University Press.

Djavann, Chahdortt. 2003. Bas les voiles! Paris: Nouvelle Revue française.

Ehrenreich, Barbara. 2004. “The New Macho Feminism”. New York Times July 29: 19. 
Feldman, Noah. 2006. “The Way We Live Now: The Only Exit Strategy Left”. New York Times July 30: 9.

Fernando, Mayanthi. 2006. "French Citizens of Muslim Faith: Islam, Secularism, and the Politics of Difference in Contemporary France". Rozprawa doktorska. University of Chicago.

Friedman, Thomas. 2006. "The Kidnapping of Democracy”. New York Times July 14: 19.

Hersch, Seymour. 2006. "Annals of National Security: The Iran Plans”. The New Yorker April 17: $30-37$.

Hirsi Ali, Ayaan. 2006. The Caged Virgin: An Emancipation Proclamation for Women and Islam. New York: Free Press.

—. 2009. Niewierna. Tłum. J. Pierzchała. Warszawa: Świat Książki.

Hitchens, Christopher. 2006. "Dutch Courage: Holland's Latest Insult to Ayaan Hirsi Ali". Slate May 22. www.slate.com/id/2142147 (dostęp: 28.08.2006).

Keshavarz, Fatemeh. 2007. Jasmine and Stars: Reading More than Lolita in Tehran. Chapel Hill: University of North Carolina Press.

Kuper, Simon. 2004. "Of All Things European: Guru of the Week-Big Thoughts in BriefAyaan Hirsi Ali”. Financial Times Weekend Magazine March 27.

http:// search.ft.com/ftArticle?queryText=kuper+hirsi+ali\&aje=true\&id $=0403270013$ 05 (dostęp: 8.03.2007).

Lazreg, Marnia. 1994. The Eloquence of Silence: Algerian Women in Question. New York: Routledge.

Mahmood, Saba. 2005. Politics of Piety: The Islamic Revival and the Feminist Subject. Princeton: Princeton University Press.

- 2006. "Secularism, Hermeneutics, and Empire: The Politics of Islamic Reformation”. Public Culture 18(2): 323-347.

Mani, Lata. 1998. Contentious Traditions: The Debate on Sati in Colonial India. Berkeley: University of California Press.

Manji, Irshad. 2005. Kłopot z islamem. Tłum. M. Świerkocki. Warszawa: Cyklady.

- 2006a. "Don't Be Fooled by the Fanatics". Times Online August 5. www.muslimrefusenik.com/news/the-times-2006-08-05.html (dostęp: 30.08. 2006).

- 2006b. "How I Learned to Love the Wall". New York Times March 18: A15.

Nafisi, Azar. 2005. Caytajac Lolitę w Teheranie. Tłum. I. Nowicka, J. Pierzchała. Warszawa: Świat Książki.

Najmabadi, Afsaneh. 1998. "Feminism in an Islamic Republic". W Islam, Gender, and Social Change. Red. John Esposito i Yvonne Haddad. New York: Oxford University Press: 59_ 84.

Pollit, Katha. 2002. "Introduction". W Nothing Sacred: Women Respond to Fundamentalism and Terror. Red. Betsy Reed. New York: Nation Books: ix-xviii.

Reed, Betsy (red.). 2002. Nothing Sacred: Women Respond to Fundamentalism and Terror. New York: Nation Books. 
Saadawi, Nawal al-. 2004. "An Unholy Alliance”. Al-Abram Weekly January 22-28. http://weekly.ahram.org.eg/2004/674/op2.htm (dostęp: 9.03.2007). Salamon, Julie. 2004. "Author Finds That with Fame Comes Image Management". New York Times June 8: E1.

Scott, Joan Wallach. 2007. Politics of the Veil. Princeton: Princeton University Press.

Spivak, Gayatri Chakravorty. 1988. In Other Worlds: Essays in Cultural Politics. New York: Routledge.

Sullivan, Andrew. 2004. "Decent Exposure”. New York Times Book Review January 25:10. 
Saba Mahmood - (1961-2018) była profesorką antropologii na University of California w Berkeley. Jej praca naukowa obejmowała debaty antropologiczne i teorię polityczną; skupiała się na społeczeństwach muzułmańskich na Bliskim Wschodzie i w Azji Południowej. Mahmood wniosła znaczący wkład teoretyczny w przemyślenie relacji między etyką i polityką, religią i sekularyzmem.

CYTOWANIE: Mahmood, Saba. 2017. „Religia, feminizm i imperium: nowe ambasadorki islamofobii." Praktyka Teoretyczna 4(26): 213-237

DOI: $10.14746 /$ prt.2017.4.8

\section{AUTHOR: Saba Mahmood}

TITLE: Religion, Feminism, and Empire: The New Ambassadors of Islamophobia

ABSTRACT: The article describes the complicity of certain currents of feminism in reproducing Islamophobic discourse. It presents writers and politicians such as Azar Nafisi, Irshad Manji, or Ayaan Hirsi Ali, who depict Islam as essentially violent and oppressive to women. Such a vision is particularly convenient to conservatives; it also serves as a support for Western imperialist projects, like the war on terrorism or interventions carried out in the Middle East under the guise of establishing democracy. This support, however, remains, invisible to some Western feminists, such as Margaret Atwood or Susan Sontag, who accept this discourse uncritically. Indeed, the aforementioned writers and activists function as "ambassadors of Islamophobia," which they seek to legitimize as "feminist" and "progressive."

KEYWORDS: feminism, Islamophobia, imperialism, the war on terror 